\title{
Influence of the Compression Ratio and Duration Injection on Performance and Emission of Sinjai Engine Type Flexible Fuel Engine 150 cc Fueled Bioethanol E70
}

\author{
Hanapi Hasan ${ }^{1}$, Bambang Sudarmanta ${ }^{1}$, Marthen Paloboran ${ }^{2}$
}

\begin{abstract}
In this study, the effects of using gasoline (E0) and gasoline-ethanol blends E70 on engine performance and exhaust emissions have been experimentally investigated. The investigation was conducted on a single-cylinder, four-stroke, spark ignition engine. The experiments were performed by varying the compression ratio and duration injection $(100 \%, 125 \%, 150 \%$, $175 \%$ and $200 \%$ ) at a speed of 2000 up to $8000 \mathrm{rpm}$ at full open throttle. The experimental results showed that blending gasoline with ethanol slightly increased the torque and decreased Carbon Monoxide (CO) and hydrocarbon (HC) emissions. It was also found that blending with ethanol allows increasing the compression ratio without knock occurrence.
\end{abstract}

Keywords_-Bioethanol E70, Compression ratio, Duration injection, Emissions, Perfomance.

\section{INTRODUCTION}

$\mathrm{T}$ he rapid depletion of the world's crude oil reserves and environmental considerations has focused on the clean, renewable and sustainable energy systems. The energy crisis and environmental pollution created an incentive to study and evaluate alcohol as a fuel in spark ignition engines [1], [2].

Renewable alternative fuels, as defined by the Energy Policy ACT of 1992 (EPACT), include alcohols (biomethanol, bioethanol and others), natural gas, liquified petroleum gas, hydrogen, coal derived liquid fuels, biofuels (include biodiesel, syntesis gas and others), and electricity [3]. They are a major force in the effort to reduce fossil fuels consumption and environmental impact (include harmful pollutans and exhaust emissions) in the transportation sectors [4]. Combustion of fossil fuel does not only produce carbon dioxide, but also $\mathrm{CO}, \mathrm{HC}$ and NOX emissions. The pollutants are endangering of human survival and all the ecosystems on the Earth [5].

At the present time ethanol is used in spark ignition engines by blending with gasoline at low concentrations without any modification. Pure ethanol can be used in spark ignition engines but necessitates some modifications to the engine [2], [6]. Some changes that can be done are changing the ignition time, change the compression ratio of the engine and as well as modify the engine fuel input system [7]. Introducing the fuels at the point of

\footnotetext{
${ }^{1}$ Hanapi Hasan, Bambang Sudarmanta are with Department of Mechanical Engineering, Faculty of Industrial Engineering, Institut Teknologi Sepuluh Nopember (ITS), Kampus ITS Sukolilo, Surabaya 60111, Indonesia. E-mail: hanapihasan7@gmail.com; sudarmanta@me.its.ac.id;

${ }^{2}$ Marthen Paloboran is with Department of Automotivel Engineering, Faculty of Engineering, Universitas Negeri Makasar, Kampus UNM Makasar, 90242, Indonesia marthen.paloboran@unm.ac.id.
}

consumption or online blending can also be used to avoid phase separation. An online fuel blending system was developed by using separate tanks for ethanol and gasoline and a stepper motor based control valve with a mixing chamber. Performance and emission characteristics with E70 (70\% ethanol in gasoline) were observed to be better than gasoline and E10 [8].

In research [9] variation in the compression ratio from 6: 1 up to 10: 1 with a gasoline ethanol mixture using concentrations of $0 \%$ (E0), 25\% (E25), 50\% (E50), 75\% (E75) and $100 \%$ (E100) indicate that when compared to E0 fuel, the power increases of $3 \%, 6 \%$ and $2 \%$ are obtained with E25, E50 and E75 fuels. In the study [4] indicate that fuel E50 with CR 9.6 has a range of initial time of combustion of $20^{\circ}-26^{\circ}$ BTDC and resulted in torque down by $4.12 \%$, while E50 CR 11.6 has a range of initial burning time of $17^{\circ}-23^{\circ}$ resulting in torque up $3,68 \%$. These parameters require a higher compression ratio, require higher pressure, and require synchronization between injection timing and ignition timing. Study of pure ethanol on a SI engine equipped with a turbocharger and a modified motor on a fuel line system, a cylindrical geometry and raised the compression ratio from 9.5 to 12.5 [10]. The 12.5 compression ratio is selected to optimize engine efficiency. At full load, the maximum torque and power generated is $15 \%$ greater than gasoline fuel.

In the study [11] investigate effect of the compression ratio on the performance of the gasoline engine with a mixture of $78 \% 22 \%$ gasoline ethanol (E22) or ethanol hydrate (E100). Variations in speeds in the range of 1,5006,500 rpm with three compression ratios tested were 10: 1 , 11: 1 and 12: 1 . The results showed that higher compression ratios improved engine performance for both fuels throughout the tested speed range, with major effects observed when ethanol hydrate was used. [12] In his 
research, found that torque E60 shows the highest increase of $14 \%$ when the compression ratio increases from 8: 1 to 13: 1. [13] investigate effect of the mixture of ethanol and unleaded gasoline (E0, E10, E20, E40 and E60), ignition timing and compression ratios for performance and exhaust emissions. Increased torque on all ethanol additions occurred at 10: 1 compression ratio, the largest $\mathrm{CO}$ decrease (32\%) occurred there was E40 and compression ratio 9: 1 while the greatest HC decrease (31\%) occurred at E60 and compression ratio 10: 1.

\section{METHOD}

This study uses the Sinjai engine type Flexible Fuel Engine 150 cc with literature studied on the use of bioethanol fuel. For standard data, tested on a fuel engine Pertamax (RON 92) with a standard ECU and a Programmable ECU. Furthermore, for the test data, performed with ECU Programmable and bioethanol fuel E70 (RON 109). This test uses a waterbrake dynamometer and is done in fully open throttle condition with engine rotation of 2000, 3000, 4000, 5000, 6000, 7000, and 8000 rpm. In the test data, a fuel injection test was performed to achieve AFR bioethanol E70 with injection percentages of $100,125,150,175$ and 200 percent of the total fuel injection standard and compression ratio which has been changed to 12, 12,5, and 13. At each engine rotation change, data recording includes torque, consumption time of $25 \mathrm{ml}$ of fuel, exhaust emissions and temperature (exhaust, engine and oil).

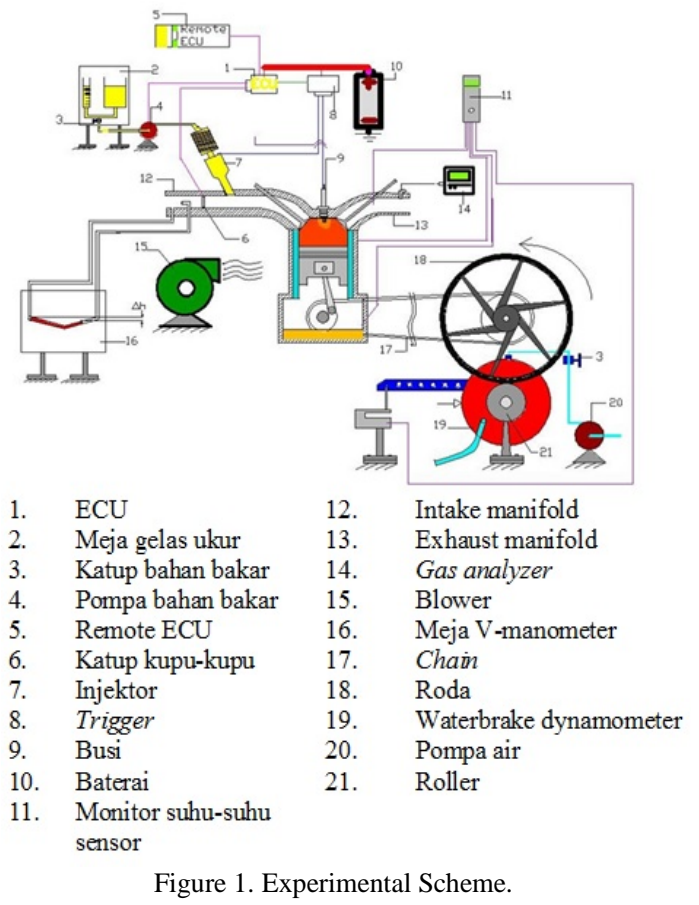

\section{RESULT AND ANALYSIS}

A. Engine Performance Analysis Using Pertamax Fuel (RON 92)

From the tests that have been done, obtained data in the form of torque from engine on the use of Pertamax fuel (RON 92) with standard ECU and ECU programmable. The test is done at engine speed of 2000 to $8000 \mathrm{rpm}$. Measurements of the torque released by the engine are carried out using a waterbrake dynamometer that has been installed with load cell already equipped with data acquisition, so that the result of the test can be directly read on the monitor in the form of torque data with unit kgf.m, which will be converted and processed first Before it is presented in graphical form. The engine torque measurement data can be shown in figure 2 below.

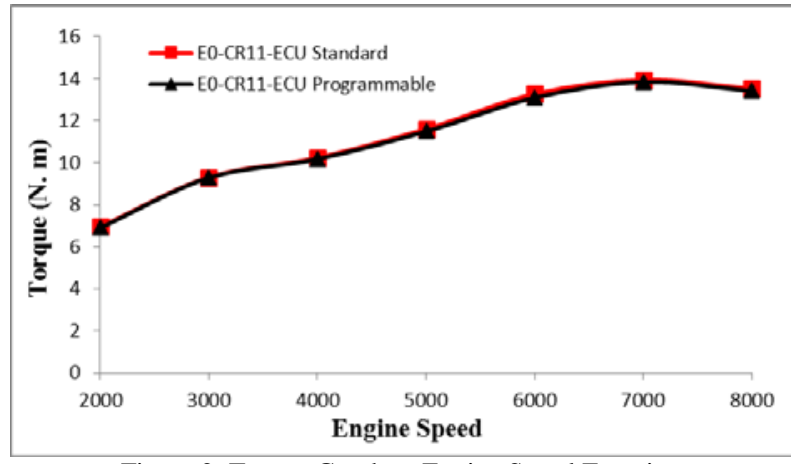

Figure 2. Torque Graph as Engine Speed Function

From figure 2 above shows the trendline that represents the torque of the engine at each engine rotation and the type of ECU used. The torque generated by the Sinjai engine on both ECU types will increase as engine speed increases from $2000 \mathrm{rpm}$ to $7000 \mathrm{rpm}$ and will decrease at $7000 \mathrm{rpm}$ engine speeds up to $8000 \mathrm{rpm}$. In the standard ECU, the resulting torque of 6.958 N.m at $2000 \mathrm{rpm}$ rotation which then will tend to rise until it reaches maximum torque at $7000 \mathrm{rpm}$ rotation of $13.936 \mathrm{~N} . \mathrm{m}$ and then the torque of the engine will decrease to $13.524 \mathrm{~N} . \mathrm{m}$ at $8000 \mathrm{rpm}$ rotation. In the programmable ECU, the resulting torque of 6.909 N.m at $2000 \mathrm{rpm}$ rotation will then tend to rise until it reaches maximum torque at $7000 \mathrm{rpm}$ rotation of 13.838 N.m and then the torque of the engine will decrease up to 13.416 N.m at $8000 \mathrm{rpm}$ rotation.

The increase in torque as the engine spins increases due to the higher rotation, the airflow entering the combustion chamber is more turbulent which will cause the air and fuel mixture to become better, so the torque will increase. In addition, increased engine speed is caused by increasing fuel flow rate, so with more fuel coming into the combustion chamber, the resulting torque will increase. But increased engine speed will also increase friction, increase operational temperature, and increase the likelihood of incomplete combustion resulting in decreased torque.

From the above data can be calculated that at $2000 \mathrm{rpm}$ rotation, torque decrease will occur by $0.7 \%$ when replacing the standard ECU with programmable ECU. At $7000 \mathrm{rpm}$ rotation, the torque decrease is $0.7 \%$ of the standard ECU, and at engine speed of $8000 \mathrm{rpm}$, the decrease in torque is $0.8 \%$ of the standard ECU. Despite the decrease in torque, the programmable ECU is considered feasible for use in this study because the reduced torque is very small. Therefore, the further analyzes are compared with E0 with the use of programmable ECU. 
B. Performance Analysis of Fuel Engine Bioethanol E70 (RON 104) Variation in Fuel Injection Duration

Prior to testing with fuel Bioethanol E70 (RON 104) variation compression ratio, then first tested with variations in fuel injection duration. This is done because Bioethanol fuel has an AFR of 9: 1. Therefore, it is necessary to increase the duration of fuel injection so that the AFR of the engine that originally 14.7: 1 can approach 9: 1. Mapping fuel injection is done to increase the incoming fuel injection from $100 \%$ to $200 \%$. The test of variation of fuel injection duration is carried out to produce maximum torque at each engine rotation by inserting mapping between $100 \%, 125 \%$, $150 \%, 175 \%$, $200 \%$ of the injector spraying discharge, then from the test result is taken maximum torsi from each engine rotation So the magnitude of mapping duration of injection of maximum fuel in each engine speed can be obtained. From the test data obtained in the form of torque from engine Sinjai engine on fuel use Bioethanol E70 (RON 104) with ECU programmable. The test is done at engine speed of 2000 to $8000 \mathrm{rpm}$. Measurements of the torque released by the engine are carried out using a waterbrake dynamometer that has been installed with load cell that has been equipped with data acquisition, so that the results of the test can be directly read on the monitor in the form of torque data with unit kgf.m, which will be converted and processed first Before it is presented in graphical form. The results of the engine torque measurements can be shown in figure 3 below.

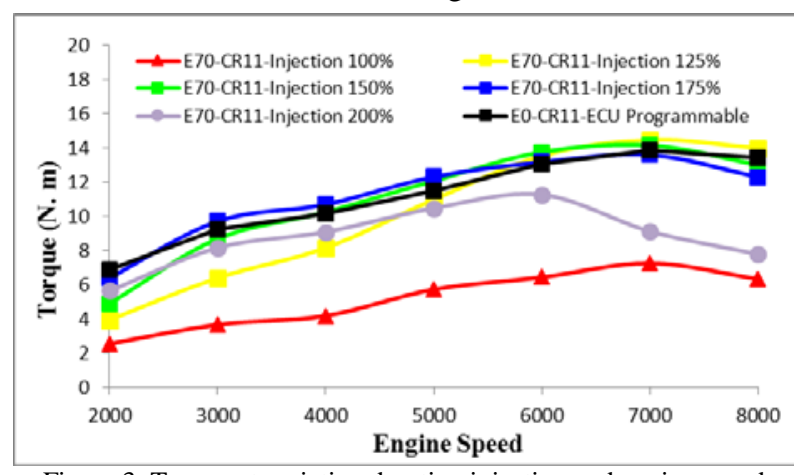

Figure 3. Torque at variation duration injection and engine speed

From figure 3 above shows the trendline representing torque at each engine rotation and variation of fuel injection duration with fuel consumption of Bioethanol E70 (RON 104). The torque generated by the duration of $100 \%, 125 \%$, $150 \%$, and $175 \%$ has a trendline that is almost the same as the trendline shown by fuel Pertamax (RON 92) that the torque value continues to increase until $7000 \mathrm{rpm}$ rotation then drops at $8000 \mathrm{rpm}$. This does not occur at 200\% duration, in this duration the torque value continues to increase until $6000 \mathrm{rpm}$ speed then dropped drastically in $7000 \mathrm{rpm}$ and $8000 \mathrm{rpm}$ rotation.

If from the above graph taken samples at $5000 \mathrm{rpm}$ rotation can be seen that by replacing fuel from Pertamax to Bioethanol E70 (with $100 \%$ injection duration), torque from engine will decrease from 11,486 N.m to 5,735 N.m. This indicates that the torque decreased by $50 \%$. Then if the duration is increased to $125 \%$, the torque generated is 10.981 N.m, so the torque decrease from Pertamax fuel usage can be reduced to $4.6 \%$. At a $150 \%$ injection duration, the torque increase occurred at $5.1 \%$ to 12.074 N.m, while the torque increased by $7.2 \%$ to 12.315 N.m on the use of $175 \%$ injection duration. Then at $200 \%$ duration, the value of torque decreased by $8.7 \%$ with a value of 10,481 N.m.

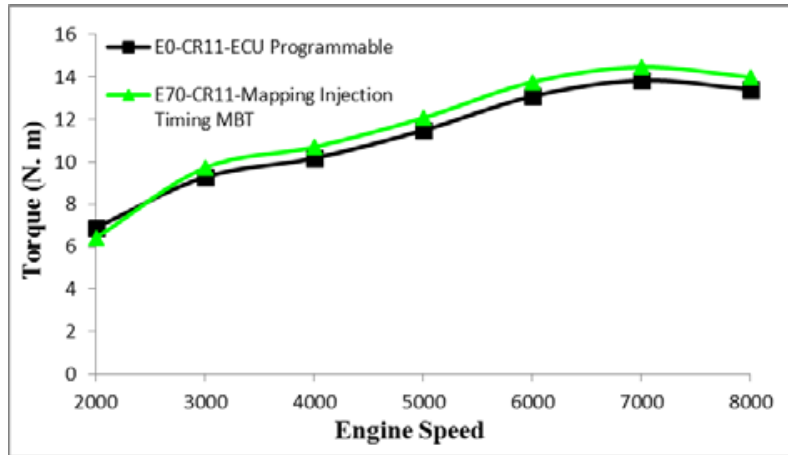

Figure 4. Torque Mapping Injection Graph as Engine Speed Function

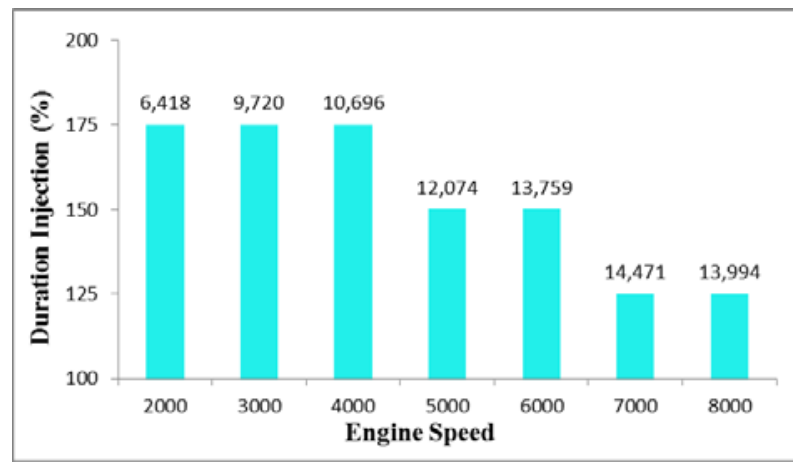

Figure 5. Optimal Injection Mapping Graph

From figure 4 it can be seen from the graph's trendline that the torque generated by injection mapping on E70 is greater than torque with Pertamax fuel (E0), so with the mapping of fuel injection duration it can be concluded that there is an increase of torque value from Pertamax fuel usage. Test results with variations of fuel injection duration on Sinjai engine shown in figure 5 obtained optimal mapping for engine Sinjai engine bioethanol fuel E70 is on the engine speed 2000 to $4000 \mathrm{rpm}$ best on $175 \%$ fuel injection mapping, 5000 engine rotation and $6000 \mathrm{rpm}$ on $150 \%$ fuel injection mapping, as well as on 7000 rotations and $8000 \mathrm{rpm}$ fuel injection mapping $125 \%$.

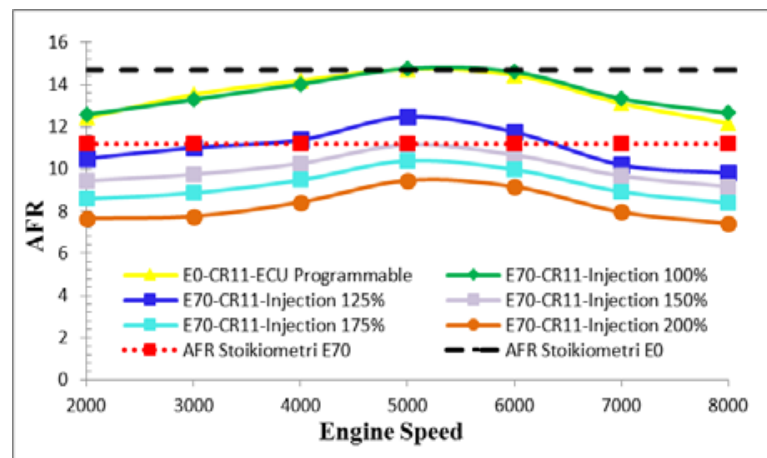

Figure 6. AFR Variation Injection Graph as Engine Speed Function 


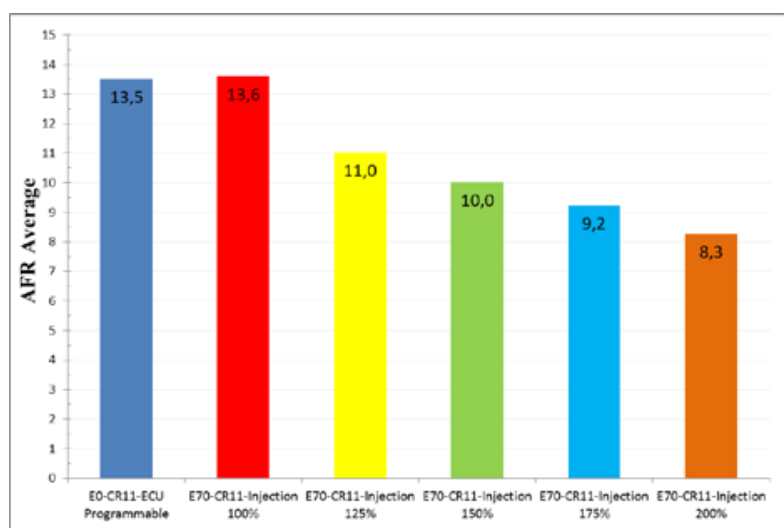

Figure 7. Graph Average AFR Variation Injection

From figure 6 it can be observed that with the replacement of the fuel into bioethanol, AFR will become poorer than that produced when using Pertamax. But with the addition of fuel injection duration up to $200 \%$, AFR will get richer. This can happen because bioethanol fuel has high latent heat. The latent high heat causes the temperature of air entering the combustion chamber to decrease as the heat from the air is absorbed by bioethanol fuel to evaporate. As a result, the air density becomes higher so the air volume becomes smaller. Because of this, then the supply of air entering the combustion chamber will be more due to the empty spaces caused by the smaller volume of air in the combustion chamber. In this condition, the mixture of fuel and air is called a poor mix (lean).

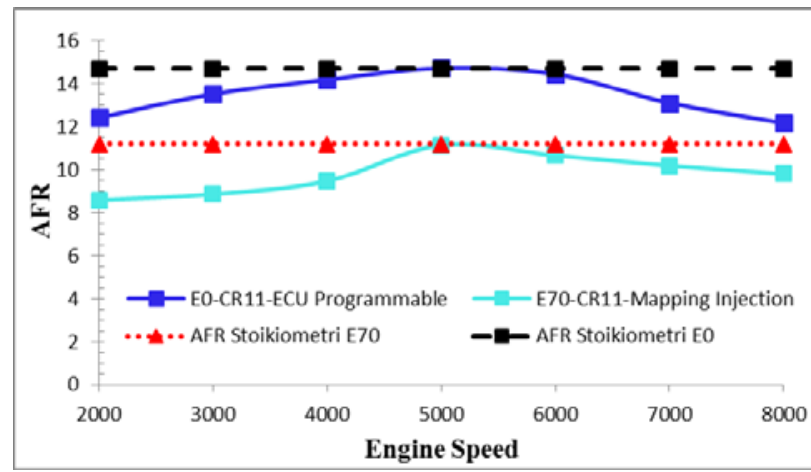

Figure 8. AFR Mapping Injection Graph as Engine Speed Speed Function

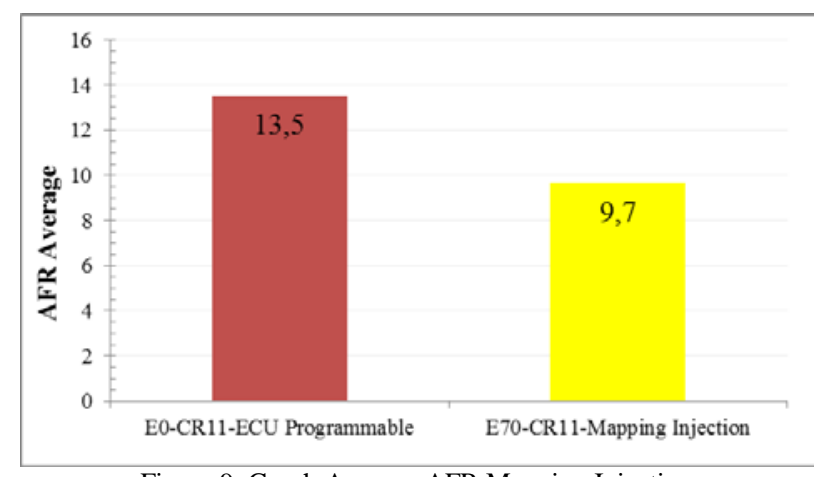

Figure 9. Graph Average AFR Mapping Injection

In the use of Bioethanol E70, by increasing the fuel injection duration from $125 \%$ to $175 \%$, the torque of the engine will be greater than $100 \%$ duration. This happens because the AFR of the engine decreases as the mass flow rate of fuel continues to increase while the air flow rate of the air is relatively constant. Each decrease from AFR
Pertamax was $18.4 \%, 25.8 \%$, and $31.7 \%$ for the duration of $125 \%, 150 \%$, and $175 \%$. This falling AFR causes more complete combustion, because AFR stoichiometry from bioethanol is 9: 1 , richer than Pertamax fuel. At a $125 \%$ injection duration, the torque generated at high rotation 7000 and $8000 \mathrm{rpm}$ is the highest value of the duration of the other injection. This occurs because of the injection duration of $125 \%$, the AFR produced is closest to the stoichiometric AFR of bioethanol. While at 200\% duration, there is a drastic reduction of torque from $6000 \mathrm{rpm}$ to 8000 rpm. This happens because the average AFR generated at the duration of $200 \%$ is $8.3: 1$. AFR is too rich for bioethanol fuel which means too much fuel supply, so that in the high torque generated will be smaller.

\section{Performance Analysis of Fuel Engine Bioethanol E70 (RON 104) Variation of Compression Ratio}

After testing the variation of fuel injection duration, then further testing with variation of ignition time and compression ratio can be done. In this test, the Sinjai engine should be set at a 13: 1 compression ratio by replacing the pistons with modified pistons with the addition of dome. After testing with 13: 1 compression ratio is complete, then the addition of packing so that the compression ratio can go down to 12.5: 1 , and 12: 1 . Testing with variation of this compression ratio aims to determine the effect on the performance, exhaust emissions, and operating temperature of the sinjai engine.

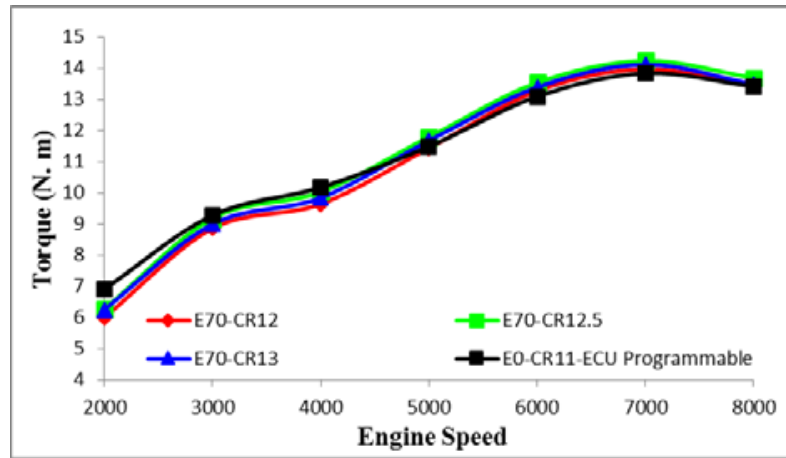

Figure 10. Graph of Torque Variation of Compression Ratio as Engine Speed Function

From Figure 10 above shows the trendline that represents the torque of the engine at each compression ratio and engine speed. Torque generated by the Sinjai engine on all variations of the compression ratio will increase along with the engine speed increase from $2000 \mathrm{rpm}$ to $7000 \mathrm{rpm}$ and will decrease at engine speed $7000 \mathrm{rpm}$ to $8000 \mathrm{rpm}$. From the above graph taken one speed engine samples at 7000 rpm for analysis, because in this engine rotation maximum torque occurs. At E70 with a compression ratio of 12.5: 1, the resulting torque of 13.974 N.m increases $1 \%$ of the torque generated by E0. At E70 with a compression ratio of 12.5: 1 , the resulting torque is 14.239 N.m and increases $2.9 \%$ of the torque generated by E0. While at E70 with a 13: 1 compression ratio, the resulting torque of $14.122 \mathrm{~N} . \mathrm{m}$ increased $2.05 \%$ of the torque generated by $\mathrm{E} 0$.

Increased torque as the compression ratio increases due to higher compression ratio, the pressure that occurs in the combustion chamber will be higher than the standard 
compression ratio of 11: 1 . Because of this higher pressure, the combustion that occurs in the combustion chamber will have a higher pressure to push the piston from the top dead point (TMA) to the lower dead point (TMB) at the engine working step, resulting in higher torque.

\section{Exhaust Emissions Analysis of Fuel Engine Bioethanol E70 (RON 104) Variation in Fuel Injection Duration}

Carbon monoxide is one of the combustion gases that are harmful to health and adversely affect the environment. The emission of CO gas in motor vehicle exhaust is caused by lack of perfect combustion in the combustion chamber. In this study more focused on the influence of fuel changes from E0 to E70, as well as the addition of injection duration and compression ratio of the engine. The increasing engine speed, the amount of CO gas emissions will increase. This is caused by incomplete combustion in the upper spin due to a mixture of fuel and increasingly rich air.

In the $\mathrm{CO}$ emission graph of engine speed, the trendline tend to be the same for fuel replacement from E0 to E70 with injection mapping. The value of CO with E0 to E70 replacement will decrease because bioethanol fuel has oxygen element in its chemical bond. The oxygen element will bind $\mathrm{CO}$ to become $\mathrm{CO}_{2}$.

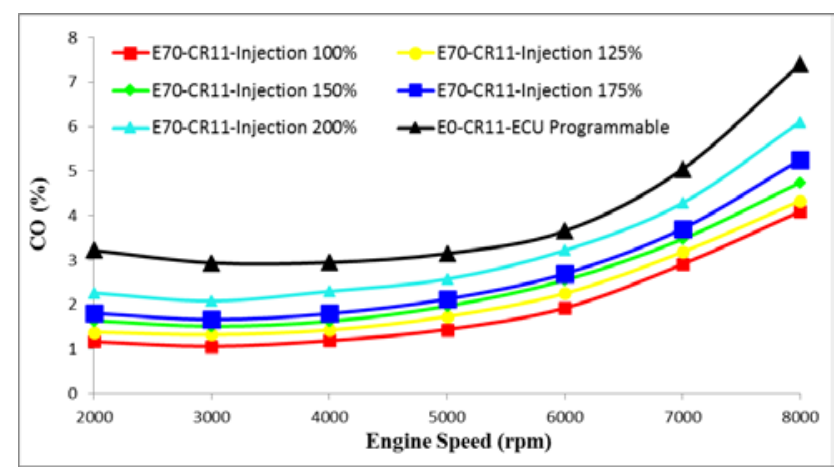

Figure 11. Carbon monoxide at variation duration injection and engine speed

HC Emissions or Unburned Hydrocarbons are the amount of fuel that does not burn in the combustion process. Theoretically HC emission levels will decrease as engine speed increases. This is due to the increased homogeneity of air and fuel mixtures as the engine speed increases. But in the upper lap, HC emissions will increase because the combustion that occurs when the lap top will be more imperfect because of the fuel mixture and the increasingly rich air in the lap top.

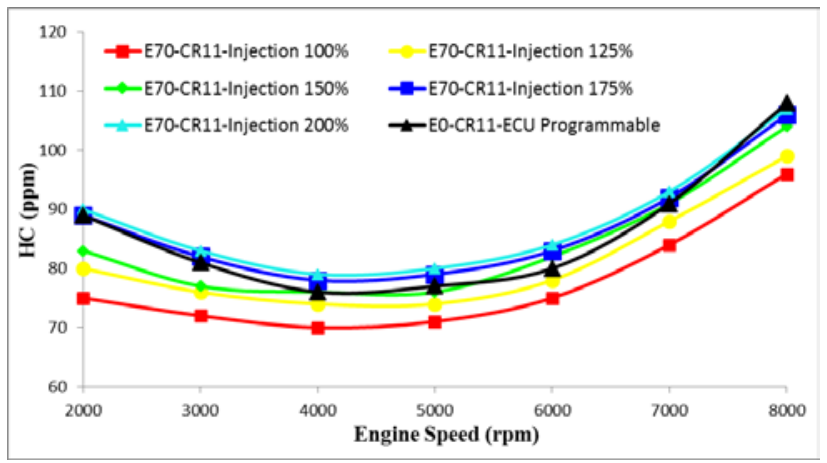

Figure 12. Hydrocarbons at variation duration injection and engine speed
Figure 12 above shows the emission of $\mathrm{HC}$ as the engine speed increases. In low rotation HC emissions tend to be high and decrease with increasing engine speed. Once the $\mathrm{HC}$ emission is at its lowest point it will increase until rpm is at $8000 \mathrm{rpm}$.

\section{CONCLUSION}

Duration injection appropriate can increase performance and reduce emissions engine. Optimal injection duration for Sinjai engine type Flexible Fuel Engine 150 cc fueled bioethanol E70 on engine speed 2000 up to 4000 rpm best on $175 \%$ fuel mapping, engine speed $5000 \mathrm{rpm}$ and 6000 rpm at $150 \%$ fuel mapping, and at engine speed 7000 and $8000 \mathrm{rpm}$ injection mapping $125 \%$.

\section{ACKNOWLEDGEMENT}

This article is part of the research activities INSINAS 2017 about testing of gasoline-bioethanol engine through Institute for Research and Community Services (LPPM) ITS. So in this opportunity, author would like to thanks RISTEKDIKTI and LPPM ITS for support that has been given.

\section{REFERENCES}

[1] W.-D. Hsieh, R.-H. Chen, T.-L. Wu, and T.-H. Lin, "Engine performance and pollutant emission of an SI engine using ethanolgasoline blended fuels,” Atmos. Environ., vol. 36, no. 3, pp. 403410, Jan. 2002.

[2] F. Yüksel and B. Yüksel, "The use of ethanol-gasoline blend as a fuel in an SI engine,” Renew. Energy, vol. 29, no. 7, pp. 1181-1191, Jun. 2004.

[3] B. Sudarmanta, S. Darsopuspito, and D. Sungkono, "Influence of Bioethanol-Gasoline Blended Fuel on Performance and Emissions Characteristics from Port Injection Sinjai Engine 650 cc,” Appl. Mech. Mater., vol. 493, pp. 273-280, Jan. 2014.

[4] B. Sudarmanta, B. Junipitoyo, A. Bachtiar, K. Putra, and I. N. Sutantra, "Influence of The Compression Ratio and Ignition Timing on Sinjai Engine Performance with 50\% Bioethanol-Gasoline Blended Fuel,” ARPN J. Eng. Appl. Sci., vol. 11, no. 4, 2016.

[5] M. E. N. Paloboran, I. N. Sutantra, B. Sudarmanta, M. E. N. Paloboran, I. N. Sutantra, and B. Sudarmanta, "Performances and Emissions Characteristics of Three Main Types Composition of Gasoline-Ethanol Blended in Spark Ignition Engines,” Int. Rev. Mech. Eng., vol. 10, no. 7, p. 552, Nov. 2016.

[6] M. Al-Hasan, "Effect of ethanol-unleaded gasoline blends on engine performance and exhaust emission," Energy Convers. Manag., vol. 44, no. 9, pp. 1547-1561, Jun. 2003.

[7] G. A. Pamuji and B. Sudarmanta, "Studi Eksperimen Pengaruh Mapping Ignition Timing Dan Durasi Penginjeksian Bahan Bakar Terhadap Unjuk Kerja Dan Emisi...,” Institut Teknologi Sepuluh Nopember, 2016.

[8] A. Kumar, D. S. Khatri, and M. K. G. Babu, "An Investigation of Potential and Challenges with Higher Ethanol-gasoline Blend on a Single Cylinder Spark Ignition Research Engine.” SAE International , 2009.

[9] M. B. Celik, "Experimental determination of suitable ethanolgasoline blend rate at high compression ratio for gasoline engine," Appl. Therm. Eng., vol. 28, no. 5-6, pp. 396-404, Apr. 2008.

[10] N. Jeuland, X. Montagne, and X. Gautrot, "Potentiality of Ethanol As a Fuel for Dedicated Engine," Oil Gas Sci. Technol., vol. 59, no. 6, pp. 559-570, Nov. 2004.

[11] R. C. Costa and J. R. Sodré, "Compression ratio effects on an ethanol/gasoline fuelled engine performance," Appl. Therm. Eng., vol. 31, no. 2-3, pp. 278-283, Feb. 2011.

[12] H. S. Yücesu, T. Topgül, C. Çinar, and M. Okur, "Effect of ethanol-gasoline blends on engine performance and exhaust emissions in different compression ratios," Appl. Therm. Eng., vol. 
26, no. 17-18, pp. 2272-2278, Dec. 2006.

[13] T. Topgül, H. S. Yücesu, C. Çinar, and A. Koca, "The effects of ethanol-unleaded gasoline blends and ignition timing on engine performance and exhaust emissions," Renew. Energy, vol. 31, no. 15, pp. 2534-2542, Dec. 2006. 